\title{
Akuttbehandling av spesialistutdanningen
}

«At en læge ved saadanne paa helt illegitimt grundlag hvilende avertissementer trækker patienter fra kolleger, som virkelig har hjemmel til at opptræde som specialister, kan i og for sig være galt nok; men værre er det, at vi læger, naar et saadant uvæsen taales, ogsaa som stand betragtet vil komme til at tabe i det oplyste publikums agtelse og sympati. [...] Skjønt lægeforeningen ikke har noget middel til ganske at afskaffe saadant skrigende uvæsen, har den dog i sin magt at træffe bestemmelser, der i hvert fald hindrer de læger, som vil være medlemmer af foreningen, fra at gaa over stregen. At saadanne bestemmelser, der allerede eksisterer i forskjellige andre lande, ogsaa i en nær fremtid bør treffes hos os, og at disse bør søge at sætte en stopper for specialistuvæsenet $\mathrm{i}$ dets helhed, det er det nu indtrufne tilfælde et varsko om.» Det «indtrufne tilfælde» som var bakgrunnen for lederartikkelen i Tidsskriftet 15. januar 1896, var at en lege allerede åtte dager etter å ha fått lisens «begyndte at avertere sig som specialist i hudsygdomme i Kristiania» (1). Utover i 1890årene ble det bl.a. i Tidsskriftet påpekt at det var et problem at leger uten noen formell kvalifisering averterte at de var spesialister. Utgangspunktet for Legeforeningens engasjement i spesialistutdanningen for leger fra slutten av 1800-tallet var altså at det var nødvendig å etablere et kollegialt system for selvjustis.

I praksis viste det seg imidlertid vanskelig å bli enig om hvordan slike spesialistregler skulle defineres og håndheves. «Krististianialægene» og «provinslægene» hadde forskjellige ønsker, muligheter og behov. Kristiania og «provinsen» likeså (2). Etter mange års debatt om hvordan man skulle løse dette, ble det på «lægemøtet» i Kristiania i 1918 vedtatt å opprette 13 spesialiteter etter bestemte regler. Det ble opprettet en «specialkomité» på fem medlemmer for hver spesialitet, og disse avga innstilling overfor Legeforeningens forretningsutvalg. Georg Benestad advarte mot et forslag som «går ut paa at erstatte samtlige specialkomiteer med en eneste stor komite paa 10 mand». En slik sentralisering ble sett på som en trussel mot kvaliteten på spesialistene (2). Flere artikler, bøker og utredninger fra de senere år har gode oppsummeringer av hvordan arbeidet med spesialistgodkjenningene og avveiningen mellom den enkelte leges, Legeforeningens og det offentliges interesser har vært i de siste 100 år. Kort oppsummert: De første spesialistreglene var rent kollegiale bestemmelser og ikke bindende for leger som ikke var medlemmer av Legeforeningen. Men reglene virket etter hensikten og ble indirekte godkjent av myndighetene. Samtidig ønsket staten sterkere styring. Allerede i 1927 åpnet lov om Lægers rettigheter og plikter for å innføre offentlig godkjenning av spesialister, men spørsmålet ble ikke realitetsbehandlet den gang. Ved lov av 13. juni 1980, nr. 42 om leger, legeloven, ble det formelle ansvar for legers spesialistutdanning tillagt Sosialdepartementet. Loven ga anledning til å delegere myndighet til å treffe enkeltvedtak om godkjenning av spesialister til Den norske legeforening. Dermed fortsatte foreningen arbeidet med utvikling av legers videre- og etterutdanning. Det nødvendige samarbeidet med Sosialdepartementet, Helsedirektoratet, de medisinske fakulteter og Norske kommuners sentralforbund fortsatte ved at disse var representert i Legeforeningens spesialitetsråd. Legeloven ble erstattet av lov av 2. juli 1999 nr. 64 om helsepersonell. Oppgaven med å godkjenne spesialister ble fortsatt delegert til Legeforeningen. Nasjonalt råd for spesialistutdanning av leger og legefordeling ble etablert fra 1. januar 1999. Staten tok med dette et enda fastere grep og et større ansvar for spesialistutdanningen.
Da legene og Legeforeningen tok initiativ til og utarbeidet retningslinjer for godkjenning av spesialister tidlig på 1900-tallet, var det for å løse et reelt problem - det at en hvilken som helst lege med lisens kunne kalle seg spesialist. Det var villedende og potensielt farlig for pasientene, det var skadelig for legenes renommé og det ga urettferdige konkurranseforhold legene imellom. I prinsippet var det liten uenighet om at en slik formalisering var fornuftig. I praksis viste det seg å være mer komplisert å bli enig om hvordan spesialistregler skulle innføres på en god måte. Legevirksomhet er basert på kunnskap fra forskning og på praktisk erfaring. Derfor mente man allerede i 1896 at bare de «der gjennem længere tids studium og under kyndig ledelse har erhvervet de specielle kundskaper og vundet den fornødne erfaring» kunne kalle seg spesialister (1). Tilegning av kunnskap og erfaring tar tid, og arbeidet må skje under «kyndig ledelse» - altså veiledning. Men hvor mye tid? Hvor mye teori? Og hvor mye veiledning fra erfarne kolleger? Det var ikke så vanskelig å bli enig om hva som ville være det ideelle. Men hva var det mulige? Og hvem skulle ha ansvaret?

Ordningen som ble etablert i 1918 var ikke perfekt, og den er fortsatt ikke det - etter utallige utredninger og tilpasninger. Reglene for spesialistutdanning skal løse mange ulike og til dels motstridende problemer. De skal ivareta den enkelte lege som spesialiserer seg, sørge for nødvendige rammebetingelser (f.eks. tid til veiledning og fordypning, tilstrekkelig antall pasienter) og dekke den norske helsetjenestens behov for legespesialister både hva gjelder antall og kompetansenivå. Og norske spesialistregler må harmonere med reglene internasjonalt. Det er ingen enkel oppskrift på hvordan dette best skal gjøres. Derfor har det vært maktkamper, diskusjoner og kontroverser, men også nødvendig samarbeid for finne kvalitativt gode og praktisk gjennomførbare løsninger.

Derfor var det en overraskende fremgangsmåte helseministeren valgte da han en fredag ettermiddag i januar 2009 presenterte det han kalte et nytt prinsipp for spesialistutdanningen nærmest over bordet (3). Helseministeren sier han vil løse et prinsipielt problem ved å overføre ansvaret for spesialistutdanningen fra Legeforeningen til staten. Dette prinsippet er jo ikke nytt. Prinsippet ble innført i 1927 og formelt gjort gjeldende med legeloven av 1980. Spesialistutdanningen er ikke først og fremst er en prinsipiell, men en praktisk og ressurskrevende oppgave med avgjørende betydning for kvaliteten på spesialisthelsetjenestene. Staten og legene har til nå hatt ganske sammenfallende mål - nemlig en kvalitativt god utdanning og et fornuftig antall spesialiteter. Det er årsaken til at det meste av det faktiske arbeidet er blitt gjort av legene selv gjennom Legeforeningen i snart 100 år.

\section{Charlotte Haug}

redaktør

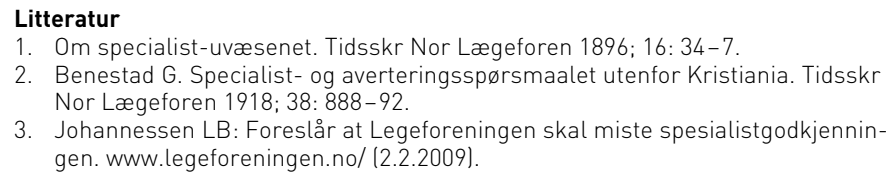

